\title{
Flexible Intermediate Bulk Container
}

National Cancer Institute

\section{Source}

National Cancer Institute. Flexible Intermediate Bulk Container. NCI Thesaurus. Code C79135.

A receptacle with a body constructed of film, woven plastic, woven fabric, paper or combination thereof, together with any appropriate service equipment and handling devices, and if necessary, an inner coating or liner. 